\title{
Universal and Culturally Specific Features and Linguistic Peculiarities of the Political Cartoon in the Arabic and French Languages
}

\author{
Natalia M. Dugalich \\ Peoples' Friendship University of Russia (RUDN University) \\ 6, Miklukho-Maklaya str., Moscow, Russian Federation, 117198 \\ dugalich-nm@rudn.ru
}

\begin{abstract}
The article discusses the universal and culturally-specific features and linguistic means of the political cartoon in the Arabic and French languages. Political cartoon is a universal tool for political dialogue between government and society, a reflection or reaction of society to a certain political event, series of events, or a person of national or world level. The goals and objectives of political cartoon, its mechanism of influence on the addressee, and its genre identity have a common tradition and common components. The study of the phenomenon of a political cartoon in various linguistic cultures is an area of relevant multidisciplinary research, primarily because the author's creative principle at the level of text and drawing interacts in the political cartoon with tradition and its genre framework, producing a capacious multilayer creolized text, the decoding of which requires from the addressee the presence of linguistic, logical and extralinguistic (primarily political and historical) presuppositions and the skills to analyze it. The object of the proposed work is a modern political cartoon in Arabic and French. The subject of the research is structural, lexical-semantic, pragmatic and cultural-specific characteristics of the creolized text of a political cartoon in the Arabic and French languages. The purpose of the work is to identify universal and culturally specific features of a cartoon on a political leader or an event at the iconic and verbal level in each of the languages under consideration. For the first time in Russian linguistics the presented study carries out a comparative analysis of the political cartoon in the Arabic and French languages and describes its universal features and cultural-specific peculiarities.
\end{abstract}

Keywords: political cartoon, creolized text, verbal component, iconic component, language means, Arabic, French

\section{Article history:}

Received: 20.05.2020

Accepted: 31.05 .2020

\section{For citation:}

Dugalich, N.M. (2020). Universal and Culturally Specific Features and Linguistic Peculiarities of the Political Cartoon in the Arabic and French Languages. RUDN Journal of Language Studies, Semiotics and Semantics, 11 (3), 479-495. doi: 10.22363/2313-2299-2020-11-3-479-495

(С) Дугалич Н.M., 2020.

This work is licensed under a Creative Commons Attribution 4.0 International License https://creativecommons.org/licenses/by/4.0/ 


\title{
Универсальные и культурно-специфические черты и языковые особенности политической карикатуры на арабском и французском языках
}

\author{
Н.М. Дугалич \\ Российский университет дружбы народов \\ ул. Миклухо-Маклая, 6, г. Москва, Российская Федерачия, 117198 \\ dugalich-nm@rudn.ru
}

В предлагаемой статье обсуждаются универсальные и культурно-специфические черты и языковые особенности политической карикатуры на арабском и французском языках. Политическая карикатура является универсальным инструментом политического диалога власти и общества, отражением или реакцией социума на некое политическое событие, ряд событий или персону национального или мирового уровня. Цели и задачи политической карикатуры, механизм влияния на адресата, ее жанровое своеобразие имеют общую традицию и общие составляющие. Изучение феномена политической карикатуры в различных лингвокультурах представляет собой сферу актуальных мультидисциплинарных исследований прежде всего потому, что авторское креативное начало на уровне текста и рисунка взаимодействует в политической карикатуре с традицией и ее жанровыми рамками, продуцируя емкий по объему многослойный креолизованный текст, декодирование которого требует от адресата наличия языковой, логической и экстралингвистической (прежде всего политической и исторической) пресуппозиций и навыков его анализа. Объект предлагаемой работы - современная политическая карикатура на арабском и французском языках. Предметом исследования являются структурные, лексико-семантические, прагматические и культурно-специфические характеристики креолизованного текста политической карикатуры на арабском и французском языках. Цель работы - выявить универсальные и культурно-специфические черты карикатуры на политического лидера или событие на иконическом и вербальном уровне на каждом из рассматриваемых языков. В представленном исследовании впервые в российской лингвистике был проведен сопоставительный анализ политической карикатуры на арабском и французском языках и описаны ее универсальные черты и культурноспецифические особенности.

Ключевые слова: политическая карикатура, креолизованный текст, вербальный компонент, иконический компонент, языковые средства, арабский язык, французский язык

\section{История статьи:}

Дата поступления: 20.05.2020

Дата приема в печать: 31.05 .2020

\section{Для цитирования:}

Dugalich N.M. Universal and Culturally Specific Features and Linguistic Peculiarities of the Political Cartoon in the Arabic and French Languages // Вестник Российского университета дружбы народов. Серия: Теория языка. Семиотика. Семантика. 2020. T. 11. no 3. С. 479 495. doi: 10.22363/2313-2299-2020-11-3-479-495

\section{Introduction}

A political cartoon is, first of all, a creolized text, a type of text that has become an integral part of modern communication. A distinctive feature of a creolized text is the inclusion in it of semiotic codes, which increases its communicative viability. 
Speaking about a political cartoon, it should be noted that the comic effect is achieved only in the synthesis of the iconic and verbal components.

In the modern world, there is a globalization rapprochement of the traditions of the political cartoon belonging to various civilizations.

Modern world political cartoons are usually printed on special editorials of newspapers or on dedicated pages for newspaper comics. Internet cartoons, including flash animation, have become widespread. In the context of globalization and the inclusion of periodicals in different languages in the general media space, political cartoons in a foreign language are becoming more accessible to the reader. An important issue of the publication of a cartoon is connected with the translation of its text and the emerging problem of the adequacy and completeness of its translation.

The following set of topics is characteristic of contemporary political cartoon: a political leader as a person, a political leader and his policy; economic reforms; election campaign; military conflicts; shadow politics and economics; reputation of the country; domestic policy of the state.

For a correct and complete perception of the author's intention in the political caricature, it is necessary to have certain presuppositions, i.e. linguistic, political, extralinguistic and logical.

Currently, several countries have institutions that document political cartoons, such as the Center for the Study of Political Graphics in the USA and the British Cartoon Archive. The importance that a political cartoon has in contemporary political discourse is confirmed by the fact that the Pulitzer Prize for Editorial Cartooning and the Press Gazette's Cartoonist of the Year Prize were awarded in Britain.

Nevertheless, we can observe the existence of cultural-specific difference between the Arab and French political cartoons:

1. French political cartoon has a long history in line with the development of European political cartoons; for Arab countries, a political cartoon is a relatively new phenomenon that sprang to life in the Middle East as a product of the expansion of the Ottoman Empire to the Arab East;

2. The main components of the French political cartoon are: theme, characters, problems, technique of execution - subsequent development of a combination of visual and textual humor/grotesque; Arab political humor has literary roots, as the tradition of visual genres did not exist for religious reasons;

3. Arab political cartoon is rapidly gaining popularity, while in France political cartoons have their own special place in the system of genres of political discourse.

\section{Methodology}

The theoretical basis of the study was the work devoted to: semiotics of the text and cognitive science: (R. Bart [1], M.M. Bakhtin [2], U. Eco [3], 
Yu.M. Lotman [4], Yu.S. Stepanov [5], I.A. Sternin [6], A. Vezhbitskaya [7]); creolized text as a special sign system with an integrative communicative effect (E.E. Anisimova [8], A.A. Bernatskaya [9], T.G. Matulevich [10], Yu.A. Sorokin and E.F. Tarasov [11], M.B. Voroshilova [12]); national-specific problems in communication (R.A. Lulu and S.N. H. Alkaff [13], V.A. Maslova [14]; E.A. Selivanova [15]; V.I. Shakhovsky, Yu.A. Sorokin and I.V. Tomasheva [16], E.M. Vereshchagin and V.G. Kostomarov [17]).

The material for this study was cartoons with a textual component in Arabic and French on political (national and world) leaders and political events. The volume of the studied material is 60 units of creolized text of a political caricature (30 in Arabic and 30 in French). The cartoons were selected by continuous sampling from the Arab and French media (newspapers), thematic blogs and websites. The problems of the cartoons under consideration include the following topics:

1) political leader;

2) election campaign;

3) domestic policy (reforms, unpopular decisions of statesmen);

4) foreign policy and international relations;

5) shadow foreign and domestic policy and economics.

\section{Universal and Culturally Specific Features of a Political Cartoon in Arabic and French}

The phenomenon of political cartoon undoubtedly has a universal beginning in nature. The analysis of topics, means of expression, the representation of verbal and iconic components on the material of the considered cartoons can be presented in the following form:

\section{Universal Features of a Political Cartoon}

According to the results of the study, the universal features of the political cartoon can be:

1. The theme of the drawings, presented by criticism of the foreign and domestic policies of a country and its leaders; satire on the aggressive course of foreign policy of world elite countries.

2. A small amount of the text component of the political caricature or its absence: the volume of the text component of the political caricature is from 1 to 30 words; the average length of an Arabic cartoon is 11.8 words; in French - 11.4 words.

3. The active use of color, which may have a traditional semantic content and play a precedent role.

4. The use of signatures and headings as elements of a cartoon.

5. Font variation.

6. Precedent images of various types. 
7. Presentation of the text in the form of a monologue and dialogue.

8. The absence of synonyms, antonyms, homonyms (one example is noted), cohyponyms and hyperonyms in syntagmatic use, which, for example, is characteristic of a literary text.

9. Use of symbols of different levels.

10. Appeal to female images.

The analysis of the examined cartoons shows that, along with universal features characteristic of political caricature as a creolized text of political discourse, we can talk about a number of distinctive features.

Theme. The material presented for analysis is a series of cartoons selected by the method of continuous sampling from newspapers, magazines and the Internet, and is affiliated with the chief editor and/or author of the cartoon. Their topic is a political leader, foreign and domestic policy of the state. The model of representation of a political leader is universal: a caricature offers a concrete action for discussion, decision or speech of a politician; assessment of the state's domestic or foreign policy under the leadership of a particular leader or commentary on the current political, historical and socio-economic situation.

The main distinguishing feature of the studied Arab and French cartoons was a large number of texts that were not explicitly associated with the figure of the President of France, the main theme of these cartoons is criticism of the socioeconomic situation in the country. In Arabic cartoons, the connection of the text with a specific political leader is expressed explicitly.

Colour. Another feature of the cartoons in Arabic is the strongly pronounced connection of the verbal component with the semiotic color code; it can be traced in $14 \%$ of the cartoons considered. The black and white version of the cartoons, which is traditional for this genre of creolized text, is more characteristic of the French caricature. Arabic cartoons, which historically come close to comics, are usually presented in multicolor form, some of them made in the tradition of a well-drawn multicolor watercolor painting.

Font variation and the presence of several text levels. The French caricature is characterized by the use of several font variation options in one creolized text, for example, highlighting certain words or letters in red, using a bold version for headings in separate words, using different font types, scaling a font of the same type. For the Arabic verbal component, font variation is less characteristic. An important difference between the Arabic text of the caricature is the use of signatures in it, mainly on the objects and attributes of the political leader.

Precedent images. In general, the principle of applying precedent images at the level of text, drawing and their hybrid use (drawing + text) is a universal feature for the Arabic and French cartoons. The national-cultural component of precedence makes the caricature incomprehensible for those recipients who are not able to decode the applied national or regional precedent phenomena (onyms 
or mentioned events), however, it allows realizing the author's intention in introducing the historical background into the cartoon, indicating the place of the event, the event's assessment by the author.

Symbols of different levels. Political cartoon, as well as a political poster, frequently uses symbolism, first of all, as a way of compact information input. We consider a national cultural difference as the frequency of use of regional symbols in the Arabic cartoon; in the French caricature, world symbols are more common.

Appeal to female images. The national-cultural specificity of the political cartoon in French implies the use of female images in the meaning of «strong woman», «equal or stronger partner» and «politician». In the Arabic cartoon, we noted such meanings as «homeland», «revolution as a relationship with a specific leader», «mother».

Peculiarities of the use of language tools. During the study of the texts of the political cartoons in Arabic and French, a number of features were noted:

- the use of religious and dialect vocabulary in the Arabic caricature;

- numerous facts of non-observance of the norm of addressing a high-ranking official, which, apparently, is connected with the author's intention to ridicule a political leader as a figure, a politician who has failed to conduct his policy and an assessment of a political event;

- the tendency to use complete sentences in Arabic.

\section{Grammatical Features of the Text of the Cartoon in the Arabic Language}

The creolized text of a political cartoon is a combination of two inhomogeneous parts: the iconic and verbal components; the verbal component of the cartoon can be analyzed as a text according to the following criteria:

1) formal structure;

2) content structure;

3) compliance with the text;

4) use of expressive language means.

The traditional division into language levels allows us to consider the text of a political cartoon in Arabic and French from the point of view of using the grammatical and lexical means of the languages in question.

The main results of the study are proposed in Tables 1, 2, 3, 4, 5 .

Under the analysis of grammatical textual means, we understand the consideration of cases of compliance and violation of inflectional norms, the use of incomplete, complete, complex and complicated sentences, the use of multilevel organization of the text component of a specific cartoon (the presence of an inscription, signature, remarks, monologue, etc.) and punctuation marks, violation of punctuation. 
Table 1 / Таблица 1

Grammatical features of the text of the cartoon in the Arabic language / Грамматические особенности текста карикатуры на арабском языке

\begin{tabular}{|c|c|c|c|c|c|c|c|c|c|}
\hline № & $\begin{array}{l}\text { Signa- } \\
\text { tures/ } \\
\text { inscrip- } \\
\text { tions }\end{array}$ & $\begin{array}{c}\text { Complete } \\
\text { sentences } \\
\text { (complete } \\
\text { thought) }\end{array}$ & $\begin{array}{l}\text { Incomplete } \\
\text { sentences }\end{array}$ & $? !$ & $\ldots / \ldots !$ & $! / ! !$ & $?$ & $\begin{array}{l}\text { Punctua- } \\
\text { tion } \\
\text { and its } \\
\text { violation }\end{array}$ & $\begin{array}{l}\text { Colloquial } \\
\text { language and } \\
\text { dialectisms } \\
\text { at the level } \\
\text { of morphology }\end{array}$ \\
\hline 1 & 1 & 3 & 0 & 1 & $0 / 0$ & $1 / 0$ & 0 & $\begin{array}{l}\text { skipping } \\
\text { full stop } \\
\text { (1) }\end{array}$ & 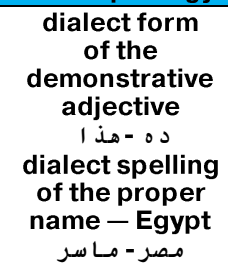 \\
\hline 2 & 1 & 2 & 0 & 0 & $0 / 0$ & $0 / 0$ & 0 & $\begin{array}{l}\text { skipping } \\
\text { full stop } \\
\text { (2) }\end{array}$ & 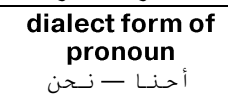 \\
\hline 3 & $\begin{array}{c}1 \\
\text { vowel } \\
\text { mark }\end{array}$ & 4 & 1 & 0 & $0 / 0$ & $0 / 0$ & 0 & $\begin{array}{l}\text { skipping } \\
\text { full stop } \\
\text { (5) }\end{array}$ & 0 \\
\hline 4 & 0 & 1 & 0 & 0 & $0 / 1$ & $1 / 0$ & 0 & $\begin{array}{l}\text { skipping } \\
\text { full stop } \\
\text { (1) }\end{array}$ & 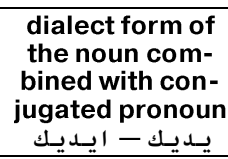 \\
\hline 5 & 3 & 1 & 0 & 0 & $1 / 0$ & $0 / 0$ & 0 & 0 & $\begin{array}{c}\text { replacement of } \\
\text { the dual number } \\
\text { with the plural } \\
\text { جزرئ }\end{array}$ \\
\hline 6 & 1 & 4 & 2 & 0 & $4 / 0$ & $0 / 1$ & 0 & $\begin{array}{l}\text { skipping } \\
\text { full stop } \\
\text { (1) }\end{array}$ & 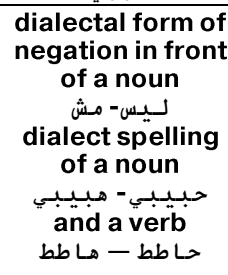 \\
\hline 7 & 6 & 1 & 0 & 0 & $0 / 0$ & $0 / 0$ & 0 & $\begin{array}{l}\text { skipping } \\
\text { full stop } \\
\text { (1) }\end{array}$ & 0 \\
\hline 8 & $\begin{array}{c}2 \\
\text { vowel } \\
\text { mark }\end{array}$ & 1 & 2 & 0 & $0 / 0$ & $0 / 0$ & 0 & 0 & 0 \\
\hline 9 & 0 & 2 & 0 & 0 & $0 / 0$ & $0 / 0$ & 0 & $\begin{array}{c}\text { skipping } \\
\text { exclama- } \\
\text { tion mark } \\
\text { (1) } \\
\text { skipping } \\
\text { full stop } \\
\text { (1) }\end{array}$ & 0 \\
\hline 10 & 0 & 0 & 1 & 0 & $0 / 0$ & $0 / 0$ & 0 & $\begin{array}{c}\text { skipping } \\
\text { exclamati } \\
\text { on mark } \\
\text { (1) }\end{array}$ & 0 \\
\hline 11 & $\begin{array}{c}2 \\
\text { vowel } \\
\text { mark }\end{array}$ & 6 & 0 & 0 & $4 / 1$ & $0 / 0$ & 0 & $\begin{array}{c}\text { skipping } \\
\text { full stop } \\
\text { (1) }\end{array}$ & $\mathrm{C}_{\mathrm{C}}$ \\
\hline 12 & 0 & 3 & 0 & 0 & $1 / 0$ & $0 / 0$ & 0 & $\begin{array}{l}\text { skipping } \\
\text { full stop } \\
\text { (1) }\end{array}$ & 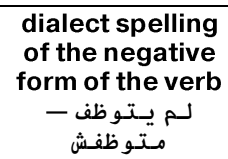 \\
\hline
\end{tabular}


Continuation of the table 1

\begin{tabular}{|c|c|c|c|c|c|c|c|c|c|}
\hline № & $\begin{array}{c}\text { Signa- } \\
\text { tures/ } \\
\text { inscrip- } \\
\text { tions }\end{array}$ & $\begin{array}{c}\text { Complete } \\
\text { sentences } \\
\text { (complete } \\
\text { thought) }\end{array}$ & $\begin{array}{l}\text { Incomplete } \\
\text { sentences }\end{array}$ & $? !$ & $\ldots / \ldots !$ & $! / ! !$ & $?$ & $\begin{array}{l}\text { Punctua- } \\
\text { tion } \\
\text { and its } \\
\text { violation }\end{array}$ & $\begin{array}{l}\text { Colloquial } \\
\text { language and } \\
\text { dialectisms } \\
\text { at the level } \\
\text { of morphology }\end{array}$ \\
\hline 13 & 0 & 2 & 0 & 0 & $0 / 0$ & $0 / 0$ & 0 & $\begin{array}{l}\text { skipping } \\
\text { full stop } \\
\text { (2) }\end{array}$ & 0 \\
\hline 14 & 2 & 0 & 0 & 0 & $0 / 0$ & $0 / 0$ & 0 & 0 & 0 \\
\hline 15 & 0 & 2 & 0 & 0 & $1 / 1$ & $0 / 0$ & 0 & 0 & 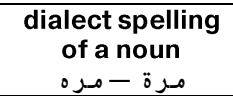 \\
\hline 16 & 4 & 2 & 0 & 0 & $0 / 0$ & $0 / 0$ & 0 & $\begin{array}{c}\text { skipping } \\
\text { exclama- } \\
\text { tion mark } \\
\text { (1) } \\
\text { skipping } \\
\text { full stop } \\
\text { (1) }\end{array}$ & 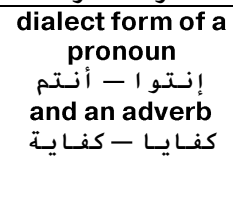 \\
\hline 17 & $\begin{array}{c}20 \\
\text { vowel } \\
\text { mark }\end{array}$ & 1 & 0 & 0 & $2 / 0$ & $0 / 0$ & 0 & 0 & 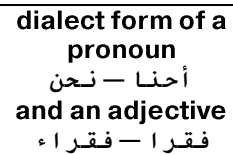 \\
\hline 18 & 2 & 2 & 0 & 0 & $1 / 0$ & $1 / 0$ & 0 & 0 & 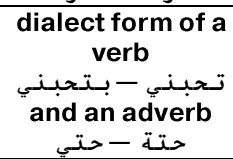 \\
\hline 19 & 0 & 5 & 1 & 0 & $2 / 0$ & $0 / 2$ & 0 & 0 & 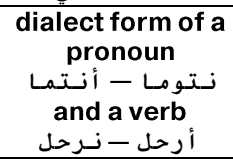 \\
\hline 20 & 2 & 2 & 0 & 0 & $1 / 0$ & $0 / 0$ & 0 & $\begin{array}{l}\text { skipping } \\
\text { full stop } \\
\text { (1) }\end{array}$ & 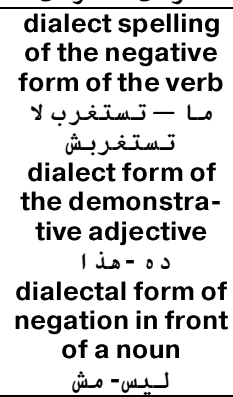 \\
\hline 21 & 0 & 1 & 0 & 0 & $0 / 0$ & $0 / 0$ & 0 & $\begin{array}{l}\text { skipping } \\
\text { full stop } \\
\text { (1) }\end{array}$ & 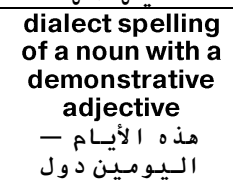 \\
\hline 22 & 1 & 2 & 0 & 1 & $1 / 0$ & $0 / 0$ & 0 & 0 & $\begin{array}{l}\text { dialect form of } \\
\text { personal pro- } \\
\text { noun } \\
\text { dialect form of a } \\
\text { diative adjective } \\
\text { relative الـذي - الـى }\end{array}$ \\
\hline 23 & 0 & 2 & 1 & 0 & $0 / 0$ & $0 / 1$ & 0 & $\begin{array}{l}\text { skipping } \\
\text { full stop } \\
\text { (2) }\end{array}$ & 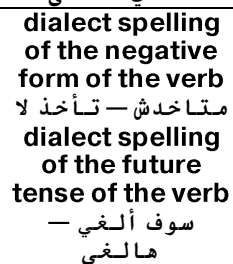 \\
\hline
\end{tabular}


End of the table 1

\begin{tabular}{|c|c|c|c|c|c|c|c|c|c|}
\hline No & $\begin{array}{c}\text { Signa- } \\
\text { tures/ } \\
\text { inscrip- } \\
\text { tions }\end{array}$ & $\begin{array}{c}\text { Complete } \\
\text { sentences } \\
\text { (complete } \\
\text { thought) }\end{array}$ & $\begin{array}{c}\text { Incomplete } \\
\text { sentences }\end{array}$ & ?! & $\ldots / \ldots !$ & !/!! & $?$ & $\begin{array}{c}\text { Punctua- } \\
\text { tion } \\
\text { and its } \\
\text { violation }\end{array}$ & $\begin{array}{c}\text { Colloquial } \\
\text { language and } \\
\text { dialectisms } \\
\text { at the level } \\
\text { of morphology }\end{array}$ \\
\hline $\mathbf{2 4}$ & 0 & 6 & 0 & 0 & $5 / 0$ & $1 / 0$ & 0 & $\begin{array}{c}\text { skipping } \\
\text { full stop } \\
\text { (1) }\end{array}$ & 0 \\
\hline $\mathbf{2 5}$ & 4 & 0 & 0 & 0 & $0 / 0$ & $0 / 0$ & 0 & 0 & 0 \\
\hline $\mathbf{2 6}$ & 1 & 0 & 1 & 0 & $0 / 0$ & $0 / 0$ & 0 & $\begin{array}{c}\text { skipping } \\
\text { ellipses } \\
\text { (1) }\end{array}$ & 0 \\
\hline $\mathbf{2 7}$ & 0 & 2 & 0 & 0 & $2 / 0$ & $0 / 0$ & 0 & 0 & 0 \\
\hline $\mathbf{2 8}$ & 1 & 2 & 0 & 0 & $2 / 0$ & $0 / 0$ & 0 & 0 & 0 \\
\hline $\mathbf{2 9}$ & 2 & 0 & 0 & 0 & $0 / 0$ & $0 / 0$ & 0 & 0 & 0 \\
\hline $\mathbf{3 0}$ & 3 & 0 & 0 & 0 & $0 / 0$ & $0 / 0$ & 0 & 0 & 0 \\
\hline
\end{tabular}

Table 2 / Таблица 2

Text structure of cartoons in Arabic / Структура текста карикатур на арабском языке

\begin{tabular}{|c|c|c|c|c|}
\hline & Monologue & Dialogue & Polylogue & $\begin{array}{c}\text { Signature/ } \\
\text { no text/author's } \\
\text { comment }\end{array}$ \\
\hline Arabic cartoon & 16 & 6 & 1 & 7 \\
\cline { 2 - 5 } & $54 \%$ & \multicolumn{2}{|c|}{$23 \%$} & $23 \%$ \\
\hline
\end{tabular}

Thus, at the morphological level of the cartoon in Arabic, the grammatical norms of the classical Arabic language are not observed, we noted numerous facts of the use of morphological dialect forms, for example:

1. future tense of the verb in the Egyptian dialect morphological form هالغى ;

2. Egyptian dialect form of the pronoun أحنا

3. Egyptian dialect form of the adjective 1 and others.

In most cases, violation of the grammar norm is explained by the dialect division of the Arabic language. The Egyptian dialect is spoken and written by authors and potential readers of the cartoon, for example, the tendency to the loss of the dual number and its replacement by the plural: جزري.

Syrian cartoons do not give violations of the grammar of dialect genesis, because the Syrian dialect of the Arabic language is as close as possible to the literary Arabic language.

The grammatical features at the level of the combination of words in the Arabic creolized text of the cartoon have a tendency towards complete sentences (ratio 61:18), where 18 are incomplete sentences. A significant number of cartoons in Arabic are organized as a monologue (ratio 16:7), where 16 are monological cartoons (see Table 2).

The language levels adjacent to the grammar (for example, punctuation) demonstrate deviations from the norm, which can be divided into two groups of phenomena:

1) related to the characteristics of the cartoon as a genre;

2) violation of etiquette norms. 
Violations of textual punctuation norms include a skipping point, the use of a combination of punctuation expressing emotions, for example, ?!, !!, ???, etc. It should be noted that the punctuation of the Arabic language, which is currently not standardized, is not clearly codified in the field of punctuation within a sentence, especially in complex sentences with compound and subordinate conjunctions in which a comma is not placed. For instance:

إنت فارفني ف عيشتي ....ر غيف العيش رغيف العيش.! بلاش اقوللك كل بسكويت عشان قديمة... با بان

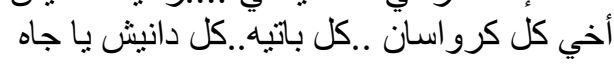

In the text fragments of the political cartoon in Arabic, the finished thought is not formed by dots or commas that would indicate the boundaries of a simple or complex sentence. We also noted variations in spelling ellipsis.

All the above linguistic facts/phenomena can be explained by the expressiveness, brevity, dialogic nature of the political cartoon, and its satirical character, i.e. they are qualitative features of a political cartoon as a genre of political discourse.

\section{Grammatical Features of the Text of the Cartoon in the French Language}

A similar study was conducted on the material of the French language, the main results of which we presented in table 3 .

Table 3 / Таблица 3

Grammatical features of the text of the cartoon in the French language / Грамматические особенности текста карикатуры на французском языке

\begin{tabular}{|c|c|c|c|c|c|c|c|c|c|c|}
\hline № & $\begin{array}{c}\text { Signa- } \\
\text { tures/ } \\
\text { inscrip- } \\
\text { tions }\end{array}$ & $\begin{array}{c}\text { Complete } \\
\text { sentences } \\
\text { (complete } \\
\text { thought) }\end{array}$ & $\begin{array}{l}\text { Incomplete } \\
\text { sentences }\end{array}$ & $? !$ & $\ldots / \ldots !$ & $! / ! !$ & $?$ & $\begin{array}{l}\text { Punctua- } \\
\text { tion } \\
\text { and its } \\
\text { violation }\end{array}$ & $\begin{array}{l}\text { Grammar } \\
\text { mistakes }\end{array}$ & $\begin{array}{l}\text { Colloquial } \\
\text { language } \\
\text { and dialec- } \\
\text { tisms at the } \\
\text { level of } \\
\text { morphology }\end{array}$ \\
\hline 31 & 0 & 1 & 0 & 0 & $2 / 0$ & $1 / 0$ & 0 & 0 & 0 & 0 \\
\hline 32 & 1 & 1 & 1 & 0 & $0 / 0$ & $1 / 0$ & 0 & $\begin{array}{c}\text { skipping } \\
\text { full stop } \\
\text { (1) }\end{array}$ & 0 & 0 \\
\hline 33 & 1 & 2 & 0 & 0 & $2 / 0$ & $3 / 0$ & 0 & 0 & 0 & $\begin{array}{c}\text { colloquial } \\
\text { construc- } \\
\text { tion mais là; } \\
\text { colloquial } \\
\text { construction } \\
\text { skipping the } \\
\text { first part of } \\
\text { the negation } \\
\text { j'en peux } \\
\text { plus }\end{array}$ \\
\hline 34 & 1 & 1 & 1 & 0 & $1 / 0$ & $0 / 0$ & $\begin{array}{c}1 \\
(3)\end{array}$ & 0 & 0 & 0 \\
\hline 35 & 1 & 0 & 1 & 0 & $0 / 0$ & $1 / 0$ & 0 & 0 & 0 & 0 \\
\hline 36 & 2 & 2 & 0 & 0 & $3 / 0$ & $0 / 0$ & 0 & 0 & $\begin{array}{l}\text { replacement } \\
\text { by the infini- } \\
\text { tive of the } \\
\text { past partici- } \\
\text { ple form } \\
\text { j'aiaccélérer- } \\
\text { j'ai accéléré }\end{array}$ & $\begin{array}{l}\text { colloquial } \\
\text { form } \\
\text { on a hésité }\end{array}$ \\
\hline 37 & 1 & 2 & 0 & 0 & $1 / 0$ & $0 / 1$ & 0 & 0 & 0 & 0 \\
\hline
\end{tabular}


Continuation of the table 3

\begin{tabular}{|c|c|c|c|c|c|c|c|c|c|c|}
\hline № & $\begin{array}{l}\text { Signa- } \\
\text { tures/ } \\
\text { inscrip- } \\
\text { tions }\end{array}$ & $\begin{array}{l}\text { Complete } \\
\text { sentences } \\
\text { (complete } \\
\text { thought) }\end{array}$ & $\begin{array}{c}\text { Incomplete } \\
\text { sentences }\end{array}$ & $? !$ & $\ldots / \ldots !$ & !/!! & $?$ & $\begin{array}{l}\text { Punctua- } \\
\text { tion } \\
\text { and its } \\
\text { violation }\end{array}$ & $\begin{array}{l}\text { Grammar } \\
\text { mistakes }\end{array}$ & $\begin{array}{l}\text { Colloquial } \\
\text { language } \\
\text { and dialec- } \\
\text { tisms at the } \\
\text { level of } \\
\text { morphology }\end{array}$ \\
\hline 38 & 1 & 3 & 0 & 0 & $0 / 0$ & $2 / 0$ & 1 & 0 & 0 & 0 \\
\hline 39 & 3 & 0 & 0 & 0 & $0 / 0$ & $0 / 0$ & 0 & 0 & 0 & 0 \\
\hline 40 & 2 & 1 & 0 & 0 & $1 / 0$ & $1 / 0$ & 0 & 0 & $\begin{array}{c}\text { use of the } \\
\text { preposition in } \\
\text { the place of } \\
\text { the full verb } \\
\text { Tout le monde } \\
\text { à son talon } \\
\text { d'Achille- } \\
\text { Tout le monde } \\
\text { a son talon } \\
\text { d'Achille }\end{array}$ & 0 \\
\hline 41 & 1 & 2 & 0 & 0 & $2 / 0$ & $2 / 0$ & 0 & 0 & 0 & 0 \\
\hline 42 & 1 & 0 & 0 & 0 & $0 / 0$ & $0 / 0$ & 0 & $\begin{array}{c}\text { skipping } \\
\text { exclamatio } \\
\text { n mark }\end{array}$ & 0 & 0 \\
\hline 43 & 5 & 1 & 1 & 0 & $0 / 0$ & $0 / 0$ & 0 & 0 & 0 & 0 \\
\hline 44 & 2 & 1 & 1 & 0 & $0 / 0$ & $0 / 0$ & 0 & 0 & 0 & 0 \\
\hline 45 & 3 & 0 & 0 & 0 & $2 / 0$ & $1 / 0$ & 0 & 0 & 0 & 0 \\
\hline 46 & 1 & 0 & 1 & 0 & $0 / 0$ & $1 / 0$ & 0 & 0 & $\begin{array}{c}\text { wrong use of } \\
\text { accent aigu } \\
\text { instead of } \\
\text { accent grave } \\
\text {..nous } \\
\text { méne...- } \\
\text {..nous } \\
\text { mène... } \\
\end{array}$ & 0 \\
\hline 47 & 1 & 0 & 0 & 0 & $0 / 0$ & $0 / 0$ & 0 & 0 & 0 & 0 \\
\hline 48 & 1 & 1 & 0 & 0 & $1 / 0$ & $0 / 0$ & 0 & 0 & 0 & $\begin{array}{c}\text { use of per- } \\
\text { sonal pro- } \\
\text { noun tu with } \\
\text { the impera- } \\
\text { tive verb } \\
\text { gardes }\end{array}$ \\
\hline 49 & 3 & 1 & 1 & 0 & $1 / 1$ & $1 / 0$ & 0 & 0 & 0 & $\begin{array}{l}\text { colloquial } \\
\text { use of pa- } \\
\text { remia p'tain } \\
\text { de merde }\end{array}$ \\
\hline 50 & 1 & 0 & 1 & 0 & $0 / 0$ & $1 / 0$ & 0 & 0 & 0 & $\begin{array}{l}\text { colloquial } \\
\text { use of c'est } \\
\text { in the mid- } \\
\text { dle of the } \\
\text { sentence }\end{array}$ \\
\hline 51 & 4 & 0 & 0 & 0 & $0 / 0$ & $2 / 1$ & 0 & 0 & 0 & 0 \\
\hline 52 & 0 & 2 & 1 & 0 & $1 / 0$ & $0 / 2$ & 0 & 0 & 0 & 0 \\
\hline 53 & 1 & 2 & 0 & 0 & $2 / 0$ & $1 / 0$ & 1 & 0 & 0 & $\begin{array}{c}\text { colloquial } \\
\text { use of the } \\
\text { verb bosser } \\
\text { instead of } \\
\text { travailler; } \\
\text { colloquial } \\
\text { form on peut }\end{array}$ \\
\hline 54 & 1 & 0 & 1 & 0 & $0 / 0$ & $1 / 0$ & 0 & 0 & 0 & \begin{tabular}{|c|}
0 \\
\end{tabular} \\
\hline 55 & 0 & 1 & 0 & 0 & $0 / 0$ & $0 / 0$ & 0 & 0 & $\begin{array}{l}\text { mistake in } \\
\text { spelling of } \\
\text { personal } \\
\text { pronoun in } \\
\text { stressed } \\
\text { form } \\
M o ̂ a-M o i\end{array}$ & $\begin{array}{l}\text { use of a con- } \\
\text { tracted form } \\
\text { of functional } \\
\text { words (le) } \\
\text { and notional } \\
\text { words (je); } \\
\text { skipping the } \\
\text { verb etre; } \\
\text { colloquial } \\
\text { form on vote } \\
\end{array}$ \\
\hline 56 & 0 & 0 & 0 & 0 & $0 / 0$ & $0 / 0$ & 0 & 0 & 0 & 0 \\
\hline 57 & 1 & 1 & 0 & 0 & $1 / 0$ & $1 / 0$ & 0 & 0 & 0 & 0 \\
\hline
\end{tabular}


End of the table 3

\begin{tabular}{|c|c|c|c|c|c|c|c|c|c|c|}
\hline No & $\begin{array}{c}\text { Signa- } \\
\text { tures/ } \\
\text { inscrip- } \\
\text { tions }\end{array}$ & $\begin{array}{c}\text { Complete } \\
\text { sentences } \\
\text { (complete } \\
\text { thought) }\end{array}$ & $\begin{array}{c}\text { Incomplete } \\
\text { sentences }\end{array}$ & ?! & $\ldots / \ldots !$ & $! / ! !$ & $?$ & $\begin{array}{c}\text { Colloquial } \\
\text { Punctua- } \\
\text { language } \\
\text { tion } \\
\text { and its } \\
\text { violation }\end{array}$ & $\begin{array}{c}\text { Grammar } \\
\text { mistakes } \\
\text { tisms alec- } \\
\text { level of } \\
\text { morphology }\end{array}$ \\
\hline 58 & 2 & 0 & 0 & 0 & $0 / 0$ & $0 / 0$ & 0 & 0 & 0 & 0 \\
\hline 59 & 3 & 0 & 0 & 0 & $1 / 0$ & $0 / 0$ & 0 & $\begin{array}{c}\text { skipping } \\
\text { full stop } \\
\text { (1) }\end{array}$ & $\begin{array}{c}\text { skipping } \\
\text { accent } \\
\text { aigu } \\
\text { ausrerité }-\end{array}$ \\
austérité & \\
\hline 60 & 1 & 1 & 0 & 0 & $1 / 0$ & $1 / 0$ & 0 & 0 & 0 & 0 \\
\hline
\end{tabular}

Table 4 / Таблица 4

Text structure of cartoons in French / Структура текста карикатур на французском языке

\begin{tabular}{|c|c|c|c|c|}
\hline & Monologue & Dialogue & Polylogue & $\begin{array}{c}\text { Signature/ } \\
\text { no text/author's comment }\end{array}$ \\
\hline French cartoon & 15 & 7 & 0 & 8 \\
\cline { 2 - 4 } & $50 \%$ & \multicolumn{2}{|c|}{$23 \%$} & $27 \%$ \\
\hline
\end{tabular}

In contrast to the Arabic language in the cartoons studied, in French we fix a number of grammatical errors, which can be interpreted as:

- intentional, decoding of which is simple enough for the reader, for example:

$>$ grammar mistake - misuse of accent aigu in place of accent grave - méne;

$>$ grammar mistake in writing a personal pronoun in the stressed form - môa.

Both errors indicate the low social status of the heroes of the cartoons.

- also intentional, but decoding of which is difficult for the reader:

$>$ grammar mistake: replacing the past participle form accéléré by the infinitive accélérer. This mistake indicates the low educational level of the official, who, choosing between his own income and the reduction in the number of teachers, chooses the potential deterioration in the situation with education in France;

grammar mistake: use of the preposition $\grave{a}$ in place of the full verb avoir in the 3rd person singular form of the present tense $a$, can be explained as additional attention to the vulnerability of the president due to the homonymous use of the preposition of the direction;

$>$ grammar mistake: skipping accent aigu in the lexical unit austerité, can be perceived as an additional touch to tough saving measures (= there wasn't enough paint for accent aigu in the new signboard).

Colloquial constructions, which were recorded in the text of cartoons in French, can also be considered as the deviation from grammar norms:

$>$ construction mais là is used as a sign of informal communication between the President of France and the Chancellor of Germany at dinner, where they discuss the problem of the economic crisis in Greece;

$>$ the form on a hésité confirms the low educational level of the official;

$>$ excessive use of the personal pronoun $t u$ with the verb in the form of the imperative mood gardes indicates informal communication between the presidents of the Russian Federation and the USA; 
using of c'est turnover in the middle of the sentence to increase the impact on the average person in the dialogue;

$>$ the use of the contracted form of functional words (le) and notional words (je), the omission of the verb to be (c'normal), the colloquial form (on vote) are used as the speech characteristic of the hero of the cartoon - an ordinary Frenchman.

The grammatical features at the level of the combination of words in the French creolized text of the cartoon can be described as the dominance of complete sentences over incomplete ones (ratio 20:10). A significant number of cartoons in French are presented as a monologue (see table 4).

Punctuation variation of French cartoons differs from Arab cartoons - in a French cartoon a signature can be framed by an exclamation mark, but in Arabic it cannot; scarcer are the cases of the use of ellipsis, a combination of exclamation and question marks, duplication of the exclamation mark compared to the cartoon in Arabic.

\section{The Use of Lexical Means in the Text of the Cartoons in the Arabic And French Languages}

The choice of lexical and paremiological means of the languages in question is dictated by the need to implement the author's intention. An analysis of the main features of the use of vocabulary of the Arabic and French languages is presented in table 5 .

Table 5 / Таблица 5

The use of lexical means in the text of the cartoon in the Arabic and French languages / Использование лексических средств в тексте карикатуры на арабском и французском языках

\begin{tabular}{|c|c|c|}
\hline Lexical means & Cartoon in Arabic & Cartoon in French \\
\hline & example & example \\
\hline polysemic units & 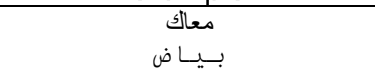 & $\begin{array}{l}\text { fou } \\
\text { soutient }\end{array}$ \\
\hline $\begin{array}{l}\text { obscene } \\
\text { vocabulary }\end{array}$ & هـا لـنغـي امسـا & $\begin{array}{c}\text { bouffon } \\
\text { con } \\
\text { p'tain de merde, } \\
\text { fait chier } \\
\text { putain } \\
\text { bosser } \\
\text { démerdez-vous }\end{array}$ \\
\hline barbarisms & $\dot{u}$ & stop \\
\hline $\begin{array}{c}\text { paronyms/ } \\
\text { quasi-paronyms }\end{array}$ & ق قـاعـد قعدة & - \\
\hline slogans & - & $\begin{array}{l}\text { Vive la France } \\
\text { liberté, égalité, fraternité }\end{array}$ \\
\hline political clichés & 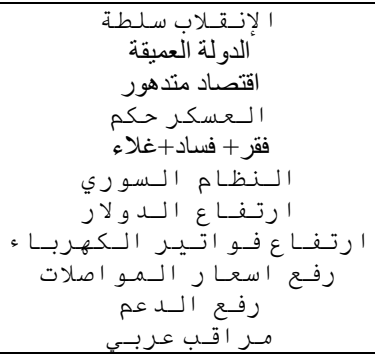 & $\begin{array}{c}\text { baisser mon salaire, supprimer des postes de } \\
\text { profs } \\
\text { Hollande allège les charges } \\
\text { Vive la France } \\
\text { la politique de l'emploi } \\
\text { échec économique } \\
\text { liberté, égalité, fraternité, austérité, précatité, } \\
\text { compétitivité } \\
\text { le taux de pauvreté }\end{array}$ \\
\hline interjections & ا & euh \\
\hline
\end{tabular}


End of the table 5

\begin{tabular}{|c|c|c|}
\hline Lexical means & Cartoon in Arabic & Cartoon in French \\
\hline onomatopoeia & - & $\begin{array}{c}\text { piiiouuu, vrrrrr, tac tac tac } \\
\text { vrooooom, bla bla bla } \\
\text { hop là }\end{array}$ \\
\hline paremiae & 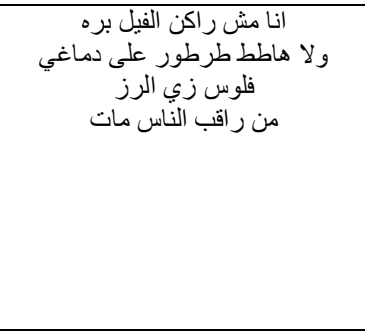 & $\begin{array}{c}\text { troubler notre repos éternel } \\
\text { ralentir mon train de vie } \\
\text { garder les clefs du poulailler } \\
\text { mettons les points sur les i! } \\
\text { talon d'Achille } \\
\text { je jetterai ma femme comme une vielle } \\
\text { chaussette } \\
\text { nous mène droit au mur } \\
\text { la bourse ou la vie } \\
\text { la langue de bois }\end{array}$ \\
\hline $\begin{array}{c}\text { religious } \\
\text { vocabulary }\end{array}$ & و الله العظيم بالله & - \\
\hline $\begin{array}{c}\text { precedent } \\
\text { vocabulary }\end{array}$ & 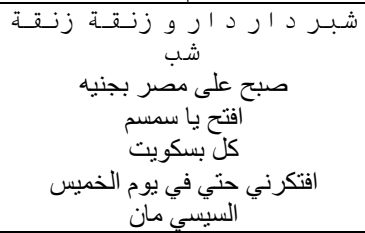 & $\begin{array}{c}\text { salade Greque } \\
\text { Goulag } \\
\text { liberté, égalité, fraternité } \\
\text { s'il te plaît, dessine-moi un ... }\end{array}$ \\
\hline
\end{tabular}

The analysis of the vocabulary of political cartoon on the chosen material allows drawing the following main conclusions.

Firstly, the relatively small amount of the verbal component of the creolized text includes a variety of lexical and paremiological means, presented in Table 5.

Secondly, at the lexical level, it is possible to single out universal features of the use of lexical means and specific linguocultural features.

The communicative task of political caricature contains components of informativeness and minimality of volume, therefore, the author of the text component must express the content quite capaciously and figuratively. This determines a relatively small number of polysemic units in the studied texts.

Here are the examples from cartoons that use the polysemic lexical unit le fou and the polysemantic verb soutenir:

\section{Syrie: la solution Poutine}

Tu gardes ton fou et je garde mon roi...

> Présidentielle: Merkel soutient Sarko

Hop là!

Cartoons in which the polysemantic words بياض are used can be an example from the Arabic language

The main purpose of choosing a polysemic unit is:

1) play on words on a verbal level;

2) correlation of one of the lexical-semantic options with the visual series to create a comic effect.

In the texts of the political cartoon considered, we noted a significant use of obscene vocabulary, which is defined by: 
1) the task of verbal characterization of a cartoon character, for example, the president in anger - p'tain de merde, fait chier;

2) enhancing the imagery of the text - bouffon;

3) underlining informality of communication, for example, political leaders - bosser;

4) by using a more colloquial member of the synonymic series to «simplify» the hero's remark - con (âne, ballot, bête, crétin, dinde, imbécile etc.).

The use of neologisms-borrowings in the political cartoon does not contribute to the communicative task of maximizing the understanding of the text by a wide circle of readers, therefore, in the texts under study we noted only two examples of the use of barbarisms: مان السيسي (which is also a precedent visual image) and, as it seems to us, a lexical unit - the verb stopper - used for brevity.

With a view to attracting the attention of the addressee, the Arabic cartoon uses paronyms قعدة and قاعدة the use of the lexical unit 'base' is justified by the iconic component and the political context, the choice of the word 'get-together' is part of a paronymic pair.

The political cartoon, following the political poster, frequently uses slogans, for example: Vive la France and liberté, égalité, fraternité, political clichés: the total number of uses is 13 (cartoons in French) and 16 (cartoons in Arabic).

The verbal component of the political cartoon contains a significant number of paremiae, which is typical for texts in both languages, for example:

$>$ troubler un repos éternel

> a spell that came from the Arabic tale «Ali Baba and the Forty Thieves».

Dialogue character of the cartoon involves the use of onomatopoeia and interjections in texts; we noted 3 cases of using interjections and 3 cases of onomatopoeia. The main goal is to convey the mood and volume of the text.

Political discourse is not free from the use of religious vocabulary, examples of which we see in Arabic texts: قسم بالله and والله العظيخ .

The emotional, manipulative, creative functions and the function of cultural memory initiate the use of precedent images and, as a result, precedent vocabulary, for example, GOULAG 'GULAG' and شبيك لبيك.

\section{Conclusion}

1) A comparative analysis of the Arab and French political cartoons revealed the presence of universal and culturally specific features of the subject of study. The most significant universals of the creolized text of a political cartoons are grammatical and lexical textual means.

2) At the grammatical level in the studied cartoons in Arabic, there are cases of deviation from the norm associated with the genre features of the cartoon, violation of etiquette norms and dialectic phenomena. In French, grammar mistakes in the text of a political cartoon can be characterized as intentional (with subsequent decoding by the addressee) and colloquial. 
3) The peculiarity of the use of lexical means in the political cartoons of the languages in question is the use of obscene vocabulary, slogans, political clichés, and paremiae.

4) A distinctive feature of the organization of the text of a political cartoon is a dialogue and a monologue. The volume of the text component of the political cartoon is $1-30$ words.

5) The specific features of the investigated cartoons are:

a) the Arabic cartoon is characterized by: use of signatures on the objects and attributes of the political leader; frequency use of supra-regional symbolism; female images are used in the meaning of homeland/revolution/mother; the use of religious and dialect vocabulary and the tendency to use full sentences;

b) the French cartoon is characterized by: font-frequency variation; the use of civilizational phenomena and world symbols; female images are used in the meaning of a strong woman/partner/politician; the use of obscene vocabulary for the speech characteristics of cartoon characters; preferential choice of a monologue in a cartoon; dominance of full sentences over incomplete ones.

\section{References}

1. Bart, R. (1989). Selected Works. Semiotics. Poetics. Moscow. (In Russ.).

2. Bakhtin, M.M. (1996). From archival records to the "Problem of Speech Genres". Moscow: Russ.kie slovari. pp. 159—207. (In Russ.).

3. Eco, U. (1998). The missing structure. St. Petersburg: Petropolis4. (In Russ.).

4. Lotman, Yu.M. (1999). Text as a meaning-generating device In Inside the thinking worlds. Man - Text - Semiosphere - History. Moscow: Languages of Russian Culture. pp. 11-163.

5. Stepanov, Yu.S. (1971). Semiotics. Moscow: Nauka. (In Russ.).

6. Sternin, I.A. (2004). Cognitive interpretation in linguistic-cognitive research. Issues of Cognitive Linguistics, 1, 65-69. (In Russ.).

7. Vezhbitska, A. (1996). Language. The culture. Cognition. Moscow: Russ.kie slovari. (In Russ.).

8. Anisimova, E.E. (2003). Linguistics of the text and intercultural communication (based on creolized texts). Moscow: Academia. (In Russ.).

9. Bernatskaya, A.A. (2000). To the problem of "creolization" of the text: history and current state. Speech communication, 3 (11), 104-110. (In Russ.).

10. Matulevich, T.G. (2017). The creolized announcement on The Economist magazine cover. RUDN Journal of Language Studies, Semiotics and Semantics, 8 (4), 383-846. (In Russ.).

11. Sorokin, Yu.A. \& Tarasov, E.F. (1990). Creolized texts and their communicative function In Optimization of speech exposure. Moscow. pp. 180-186. (In Russ.).

12. Voroshilova, M.B. (2007). Creole Text: Aspects of Learning. Political Linguistics, 21 (1), 75-80. (In Russ.).

13. Reem, A.L. \& Sharifah, N.H.A. (2019). A Cross-Cultural Study of Persuasive Strategies in Relationship Advice Articles in Women's Magazines. Journal of Language Studies, 19 (2), $15-32$.

14. Maslova, V.A. (2008). Political discourse: language games or word games? Political linguistics, 24 (1), 43-48. (In Russ.).

15. Selivanova, E.A. (2002). Fundamentals of the linguistic theory of text and communication: Monographic textbook. Kiev: TSUL, Phytosociocenter. (In Russ.).

16. Shakhovsky, V.I., Sorokin, Yu.A. \& Tomasheva, I.V. (1998). The text and its cognitiveemotive metamorphoses (intercultural understanding and linguoecology). Volgograd: Peremena. (In Russ.). 
17. Vereshchagin, E.M. \& Kostomarov, V.G. (1990). Language and culture. Linguistic studies in the teaching of Russian as a foreign language. Moscow: "Russ.kij jazyk". (In Russ.).

\section{Библиографический список}

1. Барт Р. Избранные работы. Семиотика. Поэтика. М., 1989.

2. Бахтин М.М. Из архивных записей к "Проблеме речевых жанров". М.: Русские словари, 1996. С. 159-207.

3. Эко У. Отсутствующая структура. СПб: Петрополис, 1998.

4. Лотман Ю.М. Текст как смыслопорождающее устройство // Внутри мыслящих миров. Человек - текст - семиосфера — история. М.: Языки русской культуры, 1999. С. 11-163.

5. Степанов Ю.С. Семиотика. М.: Наука, 1971.

6. Стернин И.А. Когнитивная интерпретация в лингвокогнитивных исследованиях // Вопросы когнитивной лингвистики. 2004. по 1. С. 65-69.

7. Вежбицкая А. Язык. Культура. Познание. М.: Рус. словари, 1996.

8. Анисимова E.E. Лингвистика текста и межкультурная коммуникация (на материале креолизованных текстов). М.: Academia, 2003.

9. Бернацкая А.А. К проблеме «креолизации» текста: история и современное состояние // Речевое общение: Специализированный вестник / Краснояр. гос. ун-т; под редакцией А.П. Сковородникова. Вып. 3 (11). Красноярск, 2000. С. 104-110.

10. Матулевич Т.Г. Креолизованный анонс на обложке журнала The Economist // Вестник Российского университета дружбы народов. Серия: Теория языка. Семиотика. Семантика, 2017. Т. 8. no 4. С. 383-846.

11. Сорокин Ю.А., Тарасов Е.Ф. Креолизованные тексты и их коммуникативная функция // Оптимизация речевого воздействия. М., 1990. С. 180-186.

12. Ворошилова М.Б. Креолизованный текст: аспекты изучения // Политическая лингвистика. 2007. no 21 (1). С. 75-80.

13. Reem A.L., Sharifah N.H.A. (2019). A Cross-Cultural Study of Persuasive Strategies in Relationship Advice Articles in Women's Magazines. Journal of Language Studies, 19 (2), 15-32.

14. Маслова В.A. Политический дискурс: языковые игры или игры в слова? // Политическая лингвистика. Вып. 1(24). Екатеринбург, 2008. С. 43-48.

15. Селиванова E.A. Основы лингвистической теории текста и коммуникации: Монографическое учебное пособие. Киев: ЦУЛ, «Фитосоциоцентр», 2002.

16. Шаховский В.И., Сорокин Ю.А., Томашева И.В. Текст и его когнитивно-эмотивные метаморфозы (межкультурное понимание и лингвоэкология). Волгоград: Перемена, 1998.

17. Верещагин E.M., Костомаров В.Г. Язык и культура. Лингвострановедение в преподавании русского языка как иностранного. М.: «Русский язык», 1990.

\section{Information about the author:}

Natalia M. Dugalich, PhD in Philology, associate professor of the Department of Foreign Languages of the Philological Faculty of the Peoples' Friendship University of Russia; e-mail: dugalich-nm@rudn.ru.

\section{Информация об авторе:}

Дугалич Наталья Михайловна, кандидат филологических наук, доцент кафедры иностранных языков филологического факультета Российского университета дружбы народов; e-mail: dugalich-nm@rudn.ru. 